\title{
A case study of transitions in farming and farm labor in southwestem Idaho
}

\author{
Lisa Meierotto ${ }^{*}$ and Rebecca L. Som Castellano ${ }^{c}$ \\ Boise State University
}

Submitted August 16, 2018 / Revised O ctober 22 and November 13, 2018 / Accepted November 13, 2018 /

Published online February 21, 2019

Citation: Meierotto, L., \& Som Castellano, R. L. (2019). A case study of transitions in farming and farm labor in southwestern Idaho. Journal of A griculture, Food Systems, and C ommunity D evelopment, 8(4), 111-123.

https:/ / doi.org/ 10.5304/ jafscd.2019.084.008

Copyright (c) 2019 by the Authors. Published by the Lyson Center for Civic Agriculture and Food Systems. Open access under CC-BY license.

\begin{abstract}
Farm labor in the U.S. is undergoing significant transitions. First, fewer farmworkers are migrating in the traditional sense, and more are settling in to rural American communities. Second, more women are working in agriculture- a process referred to as the feminization of agriculture. Third, there has been an increase in so-called "recreational" crops" like marijuana and hops grown for craft microbrew beers. This paper discusses these three transitions in Southwestern Idaho. These transitions were observed during pilot research conducted in Idaho during 20172018. We present this paper as a case study of current transitions in American agriculture.
\end{abstract}

a* Corresponding author: Lisa Meierotto, Ph.D., Assistant Professor, School of Public Service, Boise State University; 1910 University D rive, ERB; Boise ID 83725 USA; +1-208-426-2658; lisameierotto@ boisestate.edu

b Rebecca L. Som Castellano, Associate Professor, Sociology, Boise State University; 1910 University D rive, RFH 214; Boise ID 83725 USA; RsomCastellano@ boisestate.edu

\section{Keywords}

Migrant Farm Labor, Feminization of Agriculture, Recreational Crops, Farmworkers, Idaho

\section{Introduction}

When one imagines the face of a farmworker in the United States, the image is typically a Latino man who migrates from field to field following seasonal crops. He is generally perceived of as a hardworking man, willing to do the job that "no American wants to do." However, this popular cultural imaginary may no longer hold true. The reality is that farm labor in the U.S. is undergoing significant transitions. Fewer farmworkers are migrating in the traditional sense, and more are settling in rural American communities. More women are working

\section{Funding Disclosure}

The authors would like to acknowledge funding for pilot research from Casita Nepantla at Boise State University, the Research Committee in the School of Public Service at Boise State University, and the College of Arts and Sciences at Boise State University. 
in agriculture, and there has been a rise in so-called "recreational" crops like marijuana, and hops grown for craft microbrew beers.

O ur pilot research has frequently illustrated these transitions. In this case study, we discuss these transitions in agriculture and specifically focus on how they are manifesting in Southwestern Idaho. We further discuss the ways in which these transitions interact and influence the well-being of farmworkers in the region, particularly women. While the data collection for this project is preliminary, the findings concerning these transitions constitute, in and of themselves, a contribution to the literature on agriculture, food systems, community development, and farmworker well-being. Further, we believe that it is critical that these findings are shared with researchers and practitioners because the transitions we highlight are occurring at a rapid pace. Importantly, we believe that the transitions are interrelated, and at the end of the paper, we address the need for additional research that considers gender, immigration status, and crop type as interrelated dynamics. We hope that this article will inspire similar research in different settings. This would allow us to compare patterns, similarities, and differences in the American West across the U.S., and even globally.

\section{Background}

In D ecember 2016, we began conducting research with Idaho agricultural workers to learn more about the challenges they face in maintaining their well-being. We focused our pilot research on food security, food provisioning strategies, housing, transportation, and employment opportunities for farmworkers. During the course of this pilot research, we noted several significant transitions underway in Idaho. In particular, we noted that there was:

1. A decrease in the number of migrant farmworkers with a corresponding increase in Latinx $x^{1}$ farmworkers who are permanent or long-term residents of Southwestern Idaho;

2. An increase in the number of women working in agriculture; and

3. An exponential growth of hops farming in Southwestern Idaho.

In this paper, we discuss these transitions, including how they interact, in the context of Idaho agriculture today. First, we discuss the field site and our methods.

\section{Field Site: Southwestem Idaho}

Southwestern Idaho is an ideal site for our research for a number of reasons (Figure 1). The area is host to a unique set of demographic features. The Boise greater metropolitan area (BMA) is home to over 700,000 people (all population estimates are from U.S. Census are for 2017). The vast majority of the population lives in Boise $(226,570)$, Meridian (over 95,000), and Nampa $(91,000)$. Caldwell is the largest town at the fringes of the metro area (over 50,000 in 2017) (United States Census Bureau, 2018).

Demographically, the BMA is quite segregated by race and ethnicity. While the state of Idaho is $13 \%$ Hispanic, the majority of the Latinx population lives on the outskirts of the BMA (Figure 2). In Ada County, which includes Boise and Meridian (the two largest cities in the state), just 7\% of the population is Latinx. However, in neighboring Canyon County, where we have focused our research, $25 \%$ of the population is Latinx. In the town of Wilder (which is in Canyon Country and is an area of significant hops production), the population is $75 \%$ Latinx.

\section{Methodology: A Grounded Theory Approach} We have utilized a mixed methods approach for this research. First, we reviewed existing data on farmworkers in Idaho. We then held two meetings

\footnotetext{
${ }^{1}$ In this paper, we utilize Latinx, a contested term that is used in both academic writing and in U.S. society more broadly as a genderneutral version of Latino/ a/ @ (Guidotti-Hernández, 2017). We also use the term Hispanic whenever the source we are citing uses the term Hispanic. In Idaho, many people use the term Hispanic rather than Latina/ o/ $\mathrm{x}$, but they are used synonymously in this paper. Lastly, when we are referring specifically to those who identify themselves as women of Latin American descent, we use the term Latina.
} 
with a farmworker advocacy organization in the region and subsequently engaged in several field site visits, including five visits to hops farms in Southwestern Idaho. These farm visits involved making observations of the farms and the farmworkers and having informal conversations with contractors and farmworkers. We also worked alongside farmworkers, including during planting and harvesting season. In addition, we conducted

Figure 1. Map with Inset of the Regional Focus Area of the Present Study

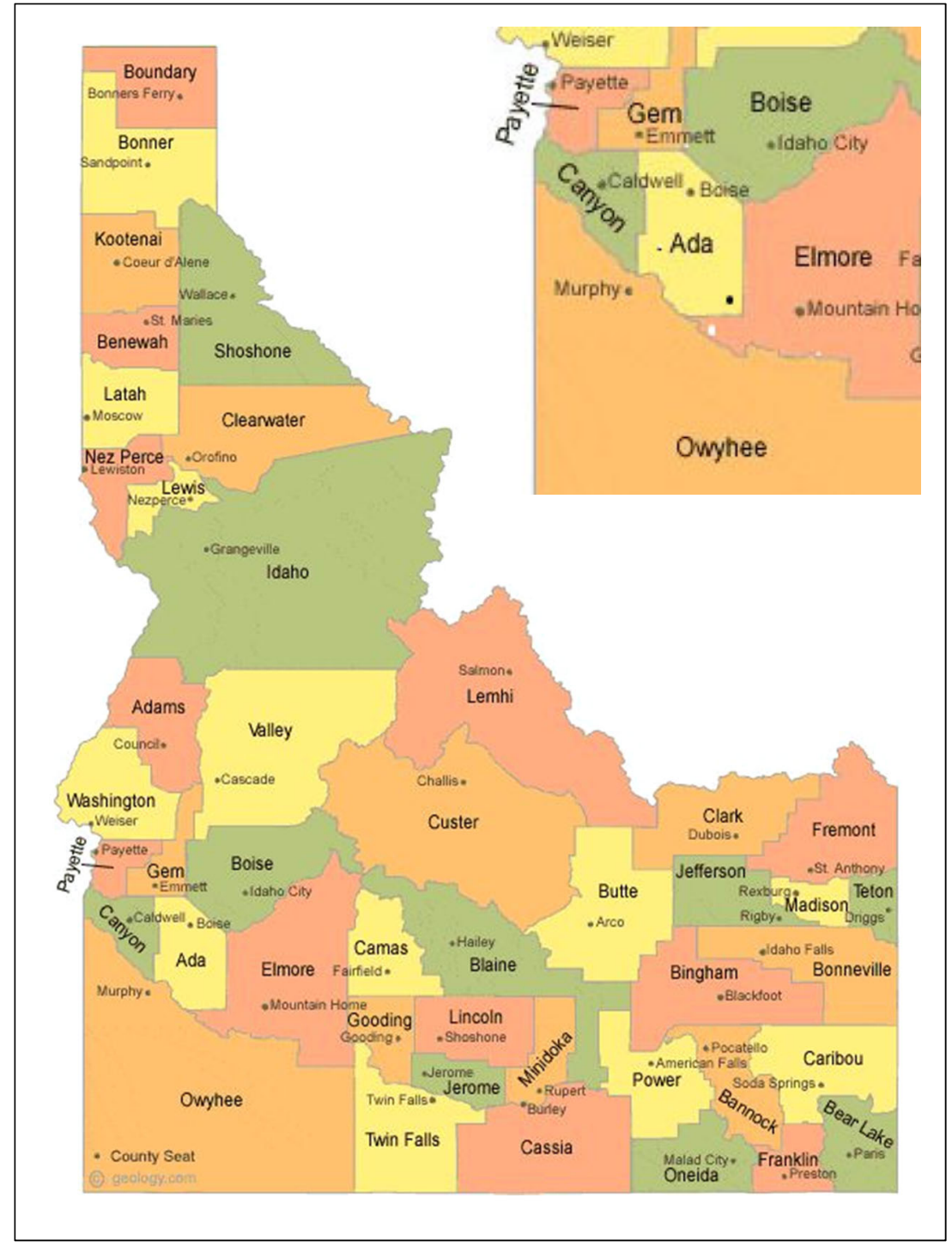

Source: Geology.com six extended interviews with (1) leaders of nonprofit organizations advocating for farmworker well-being in the region, (2) farmworker labor contractors, (3) supervisors, and (4) farmworkers. ${ }^{2}$ Finally, we collected survey data from 30 Latinx farmworkers. Surveys were completed at two Head Start parent support meetings, one in March 2017 and one in April 2018.

All ethnographic and survey data were collected after securing approval through the Boise State University Institutional Review Board. Interviews lasted between 60 and 90 minutes and were conducted in locations comfortable for the participants. Interviews occurred within the homes of research participants. All interviews were audiorecorded and then transcribed. Interviews were conducted in English or Spanish depending on the preference of the research participant. All interviews were transcribed in both English and Spanish.

Throughout our pilot research, we utilized a semigrounded theory approach; while some existing theory and data guided our questions and the findings we anticipated, we also went into pilot research with a desire to collect qualitative data to help us understand certain themes that are relevant and important to farmworkers themselves. In this paper, we are not focused on reporting the findings of our data; rather, we aim to discuss the transitions outlined above using this data to support and/ or provide a greater description of these transitions.

${ }^{2}$ Survey respondents include farmworkers of any type (not limited to hops workers). Most farmworkers in this region work a variety of crops, including, hops, onion, mint, dairy, corn, grapes, and potatoes. 


\section{Three Significant Transitions}

O ur pilot fieldwork revealed three important trends that we thought were worthy of further exploration. We discuss each transition in detail below and describe the ways in which these transitions build upon each other to influence the well-being of farmworkers in Southwestern Idaho.

\section{Transition 1: The Settling-in of Latinx Farmworkers}

The first transition we discuss here is a potential decrease in the migration of farmworkers in the region, with a rise of farmworkers settling in. Here, we are referring to migration in the traditional sense (e.g., traveling back and forth to Mexico on a seasonal basis or between agricultural locations in the U.S.). A farmworker being 'settled' is defined by the USD A as working at a single location within 75 miles (121 kilometers) of their home (U.S. Department of Agriculture, Economic Research Service [USD A ERS], 2018).

The numeric decline in migrant farmworkers has been observed across America; many agricultural workers now live permanently near their work sites (Fan, G abbard, Alves, \& Perloff, 2014). Seventy-five percent of all farmworkers now live within 25 miles ( $40 \mathrm{~km}$ ) of their work site (USD L, 2016). However, there are little data regarding the degree to which farmworkers have settled in into rural communities in Southeastern Idaho. From our observations and interviews, however, it does appear that farmworkers are increasingly settling in in the region.

There are several reasons why more Latinx farmworkers are settling in to rural communities such as those in Idaho. Border crossing became much more difficult and dangerous in the early 1990s, a result of the "Prevention through D eterrence" border security policy (Cornelius, 2004). This has likely influenced the degree to which farmworkers decided to settle in rural communities or migrate. In the region of Idaho where the hops industry is booming, the vast majority of Latinx families moved into the area prior to the 1990s. According to recent studies, $70 \%$ of Hispanics living in Idaho were born in the U.S. (University of
Figure 2. Number of Hispanics, by County, in Idaho, 2014

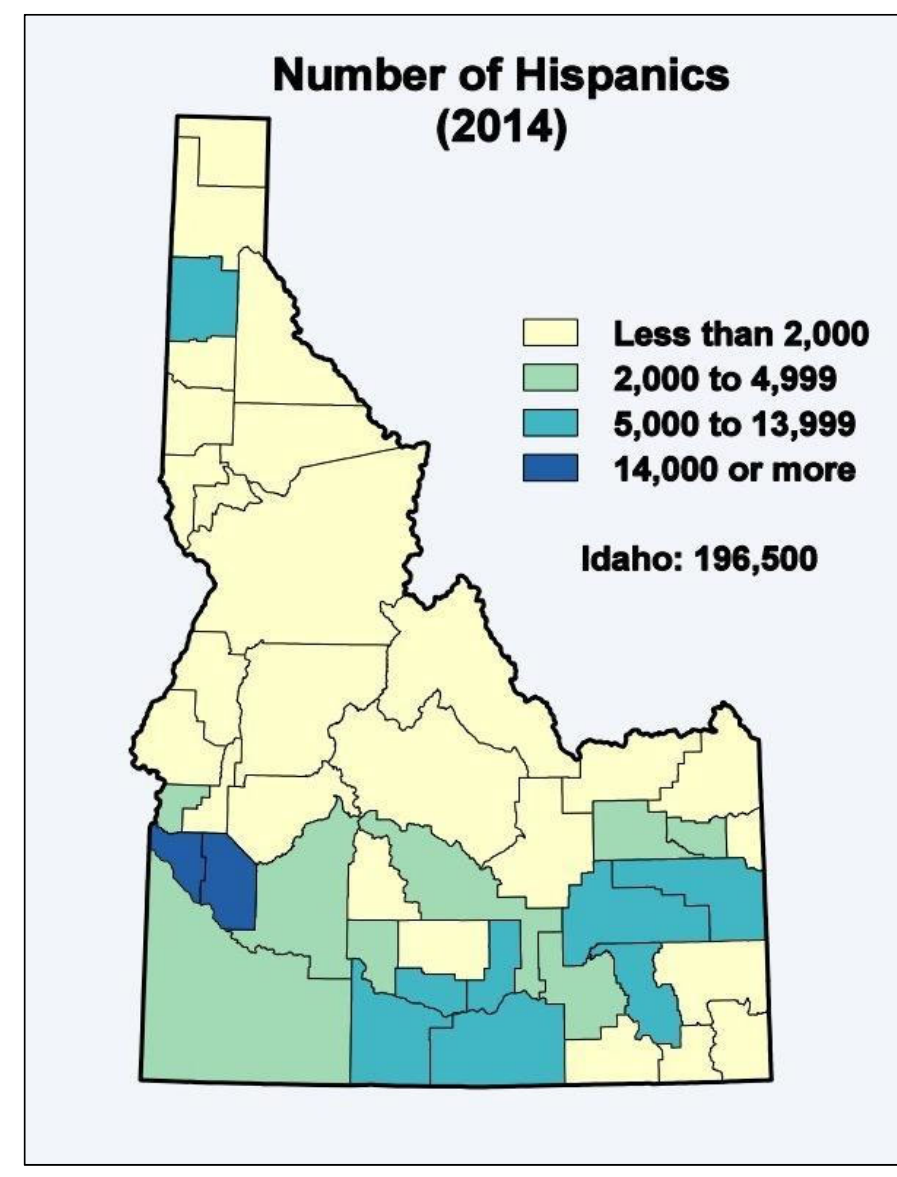

Source: University of Idaho McClure Center for Public Policy, 2016.

Idaho, McClure Center for Public Policy Research, 2016). For the 58,900 foreign-born Hispanics in Idaho, 64\% arrived in the U.S. before 2000 (University of Idaho, McClure Center for Public Policy Research, 2016). Another 30\% arrived during the 2000s, and 6\% arrived in 2010 or later (University of Idaho, McClure Center for Public Policy Research, 2016).

Interestingly, much of the research on settlingin refers to such communities as "new immigrant destinations." Schmalzbauer (2014) identifies Idaho as a "new migrant destination." These are defined as "dynamic, growing economies that have spurred population growth of the native-born as well as of migrants" (Schmalzbauer, 2014, p. 7). What this research does not always consider is the ways in which Latinx incorporation is experienced in metropolitan regions, or in communities that have historically had migrant workers. 
As the number of migrant farmworkers declines and more farmworkers settle permanently in rural Idaho, there are important socio-demographic and political considerations. As noted above, in Canyon County, Idaho, where the majority of hops production in the state occurs, the population is $25 \%$ Hispanic, the highest Latinx population in the state (US Census Bureau, 2018). With changing demographics, the political landscape can shift. As portrayed in a story on National Public Radio, Wilder, Idaho, is the first city to elect an all-Latinx city council (Rott, 2015). The demographic shifts in rural Idaho are in line with national trends. In the 1990s, there was significant growth of the Latinx population across rural America (Kandel \& Cromartie, 2004).

Within most, if not all, rural communities where Latinx farmworkers are settling in, economic and social inequalities persist. For example, rates of health insurance are significantly lower for Latinx members of rural communities, especially those communities considered to be new migrant destinations (Monat, 2017). Further, there is known rural income inequality (Parrado \& Kandel, 2010). Latinx children bom in rural America are more likely to be impoverished than Latinx born in cities (Wiltz, 2015). There is a wide body of literature that looks at rural and Latinx inequalities. While we do not have the space to review all the literature here, it is important to note the intersectionality between race and geography. Southwestern Idaho is considered to be an "established Latino population" (Crowley, Lichter, \& Turner, 2015, p. 83). Overall, established rural Latino communities fare better economically than "new" Latino destinations. However, there are still high rates of poverty. In 2010, poverty rates for established Latino communities were, on average, $26.3 \%$ for individuals, $23.4 \%$ for families with children, and $56.5 \%$ for female-headed families (Crowley et al., 2015,p. 84). The latter statistic demonstrates the ways in which race, gender, and geography intersect.

Lastly, it is important to consider citizenship status among rural Latinx farm-working populations. At the national level, approximately half of farmworkers do not have work authorization. In other words, they are undocumented workers. In Idaho, that number is estimated at approximately
45,000 individuals, composing just over $40 \%$ of the agricultural workforce (Pew Research Center, 2016). However, since 2001, the rates of citizens working in agriculture has increased from 23-27\% (U.S. D epartment of Labor [USD L], 2001; USD L, 2016). Another way that farmworkers obtain authorization to work in the U.S. is through the H$2 \mathrm{~A}$ temporary work visa program. The number of $\mathrm{H}$-2A workers has increased dramatically since 2015. According to one local source, applications for H-2A workers increased by 32\% between 20152017 (Ellis, 2017). O ur pilot research confirms this trend: farm operators are increasingly looking to the $\mathrm{H}-2 \mathrm{~A}$ program to fill labor needs. It will be interesting to observe this trend over the next few years: an increasing reliance on the $\mathrm{H}-2 \mathrm{~A}$ program in the region could shift the dynamics of farm work back toward immigrant labor.

Immigration status influences access to safety nets, particularly the Supplemental Nutrition Assistance Program (SNAP) (often referred to as "food stamps). This influences the social experiences of farmworkers in rural communities and may also limit opportunities for community organization (Carney, 2015; Crowley \& Ebert, 2014; Holmes, 2013). Thus, measures that could ease some of the mental, emotional, financial, and physical burdens for Latinx farmworkers may be inaccessible to them, particularly those who are low income and those who are not documented. Research also suggests that these conditions, including the lack of financial or physical access to food and lack of documentation, may lead Latinx farmworkers to use alternative forms of food provisioning (e.g., community gardens) (Minkoff-Zern, 2014).

There are a number of important considerations related to farmworker well-being, especially for farmworkers that have settled in. Housing is one such issue. While housing for migrating farmworkers is an issue of great concern with regard to health and well-being, it is also a concern for those who are living permanently in a community. Many of the women and families we interviewed and surveyed during our pilot research live in low-income housing. Some farmworkers live in USD A subsidized "labor camps." These are housing projects developed in the 1940s by the USD A as a way to increase seasonal farm labor in 
rural locations. They were traditionally filled with temporary workers from Mexico. Today, however, the camps serve as low-income housing in rural Idaho. The camps are still subsidized by the USD A, although some have opened to nonagricultural low-income families.

While many of the inequalities that Latinx farmworkers face persist, there are several positive outcomes related to the increasing number of Latinx farmworkers settling in is the rise in the number of minority principle operators (Figure 3). Nationally, Hispanic-operated farms increased by 21\% between 2007 and 2012. ${ }^{3}$

A recent analysis suggests that the trend of fewer migrant workers has several implications. Fan and Perloff (2016) argue that, "farmers have responded to the reduction of migrants in several ways. They have changed cropping patterns, worked harder to retain workers, made jobs more attractive to female workers, adopted labor-saving technologies, and increasingly turned to guest worker programs" (p. 7).

The next sections explore two of these phenomena in greater depth: the increase in female farmworkers and changing crop patterns.

\section{Transition 2: The Feminization of} Farm Work in Idaho The second transition we observed in our fieldwork was a feminization of farm work in Southwestern Idaho. Women represent an increasingly large percentage of the agrifood labor force in the U.S.
Figure 3. Change in the Number of Minority Principal Operators, 2007 and 2012

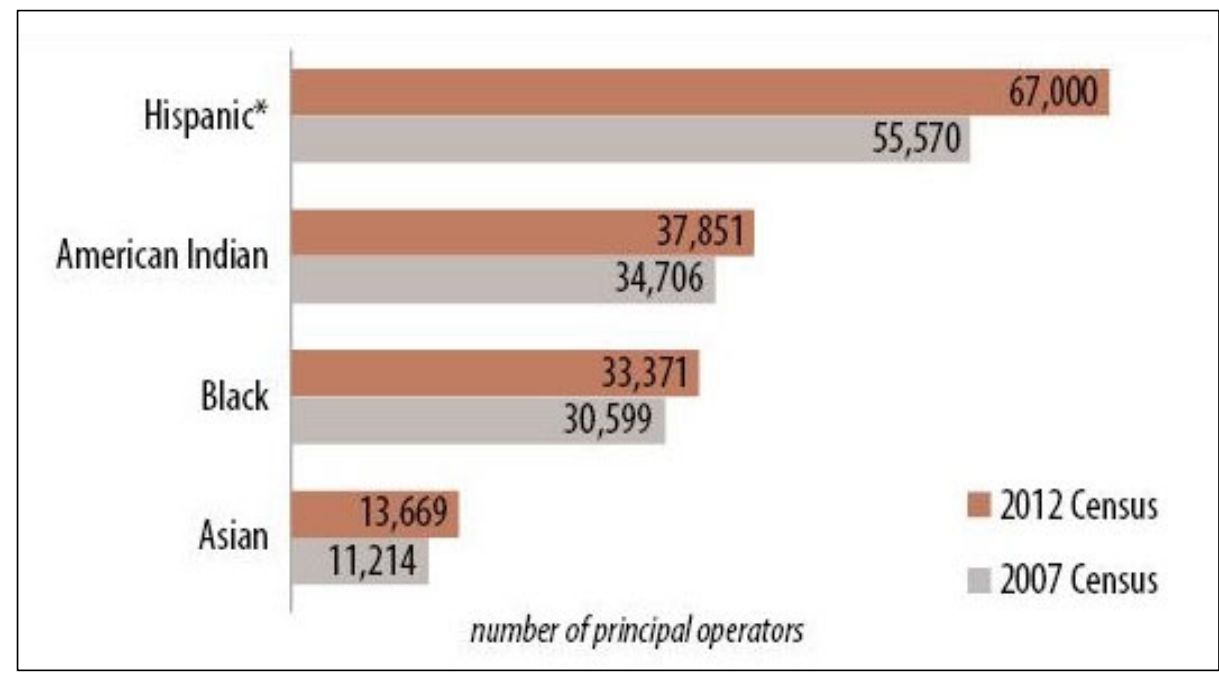

Source: U.S. Department of Agriculture National Agricultural Statistics Service, 2014. and beyond. This phenomenon is often referred to as the feminization of agriculture (LastarriaCornhiel, 2006). We begin with a discussion of the increasing role of women at the national level. We then dig deeper into this transition in Southwestern Idaho.

Nationally, the feminization of agriculture is evident at the level of farm operators. Looking at USD A Census of Agriculture data from 1978 to 2012 on the number of female farm operators per year (Table 1), we found clear evidence that more women are working in agriculture. In our analysis, the rate of change was aggregated according to farm size (following USD A standards for Gross Cash Farm Income). There was a clear increase in the ratio of female farmers across all farm sizes (Figure 4). ${ }^{4}$ However, this rate of change was most pronounced among small farms.

The feminization of agriculture in Idaho can also be seen at the level of the farmworker. Compiling data on gender from the National Agricultural Workers Survey (NAWS) between 1998 and

\footnotetext{
3 Minority farms fall disproportionately into the "farms with sales less than US $\$ 10,000$ " category.

4 USD A G lossary defines farm operator as the person who runs the farm, making the day-to-day management decisions. The operator could be an owner, hired manager, cash tenant, share tenant, and/ or partner. If the land is rented or worked on shares, the tenant or renter is the operator. In the recent Census of Agriculture and in the Agricultural Resource Management Survey (ARMS), information is collected for up to three operators per farm. In the case of multiple operators, the respondent for the farm identifies who the principal farm operator is during the data-collection process.
} 
Table 1. Change in the Percentage of Female Principle Operators, by Farm Size, Reported in the Census of Agriculture, 1978-2012

\begin{tabular}{ccccccc}
\hline Year & Acreage & Farm Size & Female Operators & Male Operators & Percent Female & Percent Male \\
\hline 1978 & $1-499$ & small & 715 & 19,964 & $3.46 \%$ & $96.54 \%$ \\
1978 & $500-1999$ & mid & 78 & 4,334 & $1.77 \%$ & $98.23 \%$ \\
1978 & $>2000$ & large & 25 & 1,239 & $1.98 \%$ & $98.02 \%$ \\
\hline 1982 & $1-499$ & small & 866 & 18,371 & $4.50 \%$ & $95.50 \%$ \\
1982 & $500-1999$ & mid & 89 & 4,024 & $2.16 \%$ & $97.84 \%$ \\
1982 & $>2000$ & large & 21 & 1,239 & $1.67 \%$ & $98.33 \%$ \\
\hline 1987 & $1-499$ & small & 1,020 & 17,670 & $5.46 \%$ & $94.54 \%$ \\
1987 & $500-1999$ & mid & 107 & 4,030 & $2.59 \%$ & $97.41 \%$ \\
1987 & $>2000$ & large & 26 & 1,283 & $1.99 \%$ & $98.01 \%$ \\
\hline 1992 & $1-499$ & small & 1,212 & 15,851 & $7.10 \%$ & $92.90 \%$ \\
1992 & $500-1999$ & mid & 137 & 3,657 & $3.61 \%$ & $96.39 \%$ \\
1992 & $>2000$ & large & 39 & 1,237 & $3.06 \%$ & $96.94 \%$ \\
\hline 1997 & $1-499$ & small & 1,537 & 15,745 & $8.89 \%$ & $91.11 \%$ \\
1997 & $500-1999$ & mid & 165 & 3,616 & $4.36 \%$ & $95.64 \%$ \\
1997 & $>2000$ & large & 47 & 1,204 & $3.76 \%$ & $96.24 \%$ \\
\hline 2002 & $1-499$ & small & 10,092 & 21,036 & $32.42 \%$ & $67.58 \%$ \\
2002 & $500-1999$ & mid & 1,172 & 4,072 & $22.35 \%$ & $77.65 \%$ \\
2002 & $>2000$ & large & 418 & 2,072 & $16.79 \%$ & $83.21 \%$ \\
\hline 2007 & $1-499$ & small & 11,383 & 21,467 & $34.65 \%$ & $65.35 \%$ \\
2007 & $500-1999$ & mid & 1,171 & 3,898 & $23.10 \%$ & $76.90 \%$ \\
2007 & $>2000$ & large & 466 & 2,042 & $18.58 \%$ & $81.42 \%$ \\
\hline 2012 & $1-499$ & small & 11,551 & 21,366 & $35.09 \%$ & $64.91 \%$ \\
2012 & $500-1999$ & mid & 1,281 & 3,917 & $24.64 \%$ & $75.36 \%$ \\
2012 & $>2000$ & large & 513 & 1,962 & $20.73 \%$ & $79.27 \%$ \\
\hline
\end{tabular}

Note: 1 acre $=0.4$ hectare

2014, we see a similar, clear increase in the percentage of women working in agriculture.

While at the national level males still make up $72 \%$ of the crop labor force (USD L, 2016), this high proportion of male workers does not match our initial observations of labor in the hops industry in Southwestern Idaho. D uring pilot research, we observed that women make up approximately half the hops workforce. Further, while there does appear to be some gender-segregated work in hops agriculture, we have observed and talked with women at all levels of hops agriculture, ranging from supervision, planting, repairing wires, driving tractors, and processing ripened vines of hops cones.
When we asked our research participants about the presence of women in the hops fields, many asserted that women possess qualities that make for good agricultural workers, including strong work ethic, reliability, and the ability to perform high-level precision labor. Looking at existing literature, there are multiple likely explanations for the increasing role of women in Idaho agriculture. O ne common explanation is that women provide a flexible labor force. The defining characteristic of the new female wage labor in Latin America and Africa is its "flexible" labor force- seasonal, temporary, or casual women workers- with an underpinning of a small, permanent, and largely male labor force. Because the world market for 
vegetables, fruit, and other fresh products such as flowers is very competitive, agribusiness seeks a flexible labor force that works long hours for only part of the year while receiving low wages and no social benefits (LastarriaCornhiel, 2008). The BMA is one of the fastest growing regions in the country. We found that such economic and population growth can lead to a rise in sectors of the economy such as construction that may pull men who have traditionally worked as farmworkers away from farm jobs, thus leaving opportunities open to women that had previously been closed to them.

The feminization of farm labor raises some important socio-cultural questions, including questions related to well-being. For instance, findings from our pilot research indicate that there are several specific concerns related to women farmworkers and their ability to provide food for their families (Meierotto \& Som Castellano, forthcoming). Many of the women we talked to during our pilot research experienced some degree of food insecurity; in fact, $50 \%$ of respondents reported some degree of food insecurity. Farmworkers and their families also struggled with access to high-quality food given their geographic isolation. O ver $75 \%$ of our study group felt they lacked sufficient money to buy the kinds of food they would like to buy.

Childcare is also an area of focus given the feminization of farm labor. As more women enter the workforce, and in particular as they work in temporary seasonal labor, child care is a pressing issue. Many of the farmworkers we have interviewed and surveyed depend on local Head Start programs for childcare. O ther families mentioned relying on relatives, neighbors, and older siblings for childcare.
There is inadequate provision of childcare, preschool, and kindergarten across the board in Idaho. Less than 30\% of three- and four-year-old children are enrolled in preschool, the lowest percentage of all states, and Idaho is one of 7 states that does not offer public preschool (National Institute for Early Education Research, 2017).

Farmworker mothers face additional barriers when it comes to providing education for their children. Rates of kindergarten preparedness are influenced by race and ethnicity: $54 \%$ of all Idaho kindergartners were ready for kindergarten, compared to just 29\% of Hispanic kindergartners (Idaho Business for Education \& J. A. and Kathryn Albertson Foundation, 2015). By many measures, there is a pronounced "ethnicity achievement gap" in Idaho, with Hispanic students performing lower than non-Hispanic students on a variety of tests (Idaho Business for Education \& J. A. and Kathryn Albertson Foundation, 2015). Largely an outcome of inequality in school funding, lack of quality education adds to the physical and psychological burdens of Latinx farmworkers in the region. For example, one mother described sending her child to the school in a nearby town, rather than the closest school, in order to provide her child with a better education. Of course, this added to her daily burdens and complicated her ability to work.

With the feminization of farm labor, we can anticipate a deterioration of workplace conditions 
(Lastarria-Cornhiel, 2006). For instance, it is well established that women typically earn lower wages than men; moreover, female labor is often viewed as temporary. We have observed this trend in Idaho; as more men find full-time, year-round employment in other sectors like dairy or construction, women have taken on more of the temporary, part-time jobs prevalent in seasonal agriculture.

The feminization of agriculture raises other questions related to well-being for women farmworkers in the region. For instance, studies have shown that women face an increased risk of pesticide exposure (Wasserman, 1999). This is due to the fact that agricultural equipment, protective wear protocols, and training regimes are typically designed for men (Andersson \& Lundqvist, 2014; Wasserman, 1992). International research has shown that women in the agricultural labor force experience different-- and typically increased--job hazards compared to their male counterparts, particularly those related to pesticide exposure. A study of work-related pesticide poisoning among farmers in southern China found that pesticide poisoning was more common among women (Zhang et al., 2011). In another study, over 70\% of female Ecuadorian workers reported that they had not been trained to wear protective gear or that their protective gear was too large (Arcia et al., 1993).

Recent research in the southeastern U.S. also suggests cause for concern regarding pesticide exposure among female farmworkers. Arcury et al. (2018), analyzed pesticide metabolites in 31 Latina farmworkers in North Carolina. These workers had significantly higher concentrations of most organophosphate (OP) metabolites than were reported for women or Mexican Americans who participated in the National Health and Nutrition Examination Survey (NHANES) for any year for which data are reported. Similarly, in a 2013 study of O P exposure among 47 Latina nursery workers in Florida, total OP metabolite levels were significantly higher among the workers than among a control population of women not involved in agricultural work (Runkle et al., 2013). To our knowledge, no data are available on pesticide exposures among Latina farmworkers in the Mountain West. Because pesticide use patterns vary widely by region and crop, this is a significant data gap.

\section{Transition 3: Rise of Hops Production in the BMA}

The third transition we discuss is an increase in hops agriculture in Southwestem Idaho. When we began our research in the region, it became immediately evident that hops production was increasing. Production of hops requires the installation of significant infrastructure, and we observed the large poles required for hops production being installed in many fields that had historically been planted in other crops, primarily onions. Many people with whom we spoke discussed the significant increase in hops production in the region, but also emphasized that this region had been producing hops for many years.

O ur observations are confirmed with recent data from the National Agricultural Statistics Service (USD A NASS, 2018). According to the USD A NASS, there has been an 18\% increase over 2017 in acres of hops production in Idaho; Idaho farmers added 1,224 acres (495 hectares), and Idaho is now the nation's number two hops-producing state, both in terms of acres planted and in total volume of production (USD A NASS, 2018). The largest hops producing county is Canyon County, which is located in the BMS (Lowe, Holley, Islam, Sandow, \& Hurt, 2016). Thus, while craft brewing has become an important part of the cultural landscape in the Northwest, it is also an important component of the regional economy. Idaho hops production in 2015 was valued at US\$30.8 million (USD A NASS, 2016).

One of the drivers of the agricultural shift to hops in Idaho is consumer demand for craft microbrew beer. According to the National Brewers Association (n.d.), craft beer sales made up more than $23 \%$ of the U.S. beer market in 2017, making craft beer an increasingly popular commodity across the U.S. This rise in craft beer consumption has also changed the landscape for hops production, as it has required a greater amount and variety of hops to be produced.

Climate change and land use change are also potential drivers of increased hops production in the region. As noted above, the BMA has one of the fastest-growing populations in the country, and considerable land conversion has been taking place in the region. Land use conversion from agriculture 
to development can make it more difficult to farm; it can also increase the price of land, thus influencing a farmer's decision-making regarding what to do with their land and agricultural operation in the future. In the short term, hops can make more money on smaller plots of land than other crops. It is also requires less large machinery. Further, water use is of particular concern in the region, and is related to urban growth, land use conversion, and climate change. Some believe that the conversion to hops production has been motivated not only by economic conditions but also because of potential water scarcity. While the region has traditionally made use of flood irrigation, many farmers are transitioning to drip or pivot irrigation; hops are a crop that thrives on drip irrigation, a potentially motivating factor for some to switch to hops production.

The increase in hops agriculture raises a number of important questions regarding farm work in the region. First, hops are a highly labor-intensive crop that requires precision and highly skilled farmworkers. Given this, and the fact that new jobs have arisen for many farmworkers in the region because of population growth and the booming economy, finding sufficient farmworkers for this skilled labor may be (or become) an increasing challenge for hops growers in the region. Y et working in the hops fields has been reported as preferable to working in other crops in the region, such as onions. We have been told that working in hops production offers higher wages and that there is more work throughout the year; in other words, it is less seasonal. However, there is no current research in the region on consumer knowledge of or attitudes towards local farm work conditions, particularly as it relates to the production of locally produced crops. Further, there is little to no organic hops production in Idaho. For example, there are no farms in Idaho listed by the American Organic Hop Grower Association (AOHGA, n.d.). An Idaho Preferred blog post from 2014 noted that there were 60 acres ( 24 ha) of organic hops in production (Idaho Preferred, 2014). Historically all of the hops produced regionally has been distributed through international distribution channels. However, it appears, at least anecdotally, that there is starting to be some increased interest or movement toward making use of local hops in the region. Recently, a few local breweries have started to highlight local hops in the production of select brews. While the debate about the benefits and drawbacks of special labeling schemes continues, it is possible that a fair-worker hops label could improve the living and working conditions of farmworkers laboring in hops in the region.

\section{Discussion and Conclusion}

In this paper, we have discussed transitions underway in agriculture and farm work in Southwestern Idaho, paying particular attention to how these transitions may influence the well-being of farmworkers. Due to their geographic, cultural, and economic isolation, concerns about the health and well-being of farmworkers are often overlooked. When attention is paid to farmworkers, it is often focused on young, male, migrant workers. Y et, in many regions, the realities of farm work, both in terms of who is doing the work and what the work looks like, may be changing. It is important to be attentive to these changes and to understand how transitions in agriculture and farm work may be intersecting, and influencing the well-being of those who work so hard to produce food and drink. The transitions described above provide insight into the ways in which agriculture and farm work in the region are changing and highlight some of the ways in which the lives and well-being of farmworkers may be influenced.

To conclude this paper, we offer a list of research questions relevant to each of the transitions discussed in the case study.

(1) Future research should closely examine the increase in farmworkers settling in the region. For example:

$\mathrm{H}$ ow does well-being vary based on whether farmwork ers in the region are settled in, relative to those who are migrating?

W hat socio-, economic, or political challenges do settled L atinx farmwork ers face?

$\mathrm{D} 0$ the current political dimate and immigration policy proposals influence the plans of farmworkers 
who have settled in in the region? $\mathrm{H}$ ow does this vary based on generation, country of origin, and citizenship status?

(2) Future research should determine if there is a quantitative increase in women working in agriculture, not just in Idaho, but also across the United States. Further, the feminization of agricultural labor in Idaho raises a number of questions regarding farmworker well-being. For example,

$\mathrm{H}$ ow do the risk s of pesticide ex posure differ between women and men farmwork ers?

W hat safety risks ex ist for women work ing in the fields? F or instanœ, is safety equipment available in women's sizes?

D 0 women farmwork ers face additional challenges in ensuring well-being for their families?

A re there different ways that women farmwork ers need social support- such as with child care, grocery store aœess, and flex ible work ing hours?

(3) We suggest a wider study of labor in hops agriculture across the Northwest. Q uestions to consider include:

D o farmers report changes in the labor force who are work ing in hops production?

W hat challenges do farm owners face with regards to labor in their operations?
(4) Lastly, we propose additional research on beer consumers, especially in the Northwestern U.S. For example:

Is there an awareness among microbrew consumers that hops are a labor-intensive crop?

Is there an interest in pursuing fair-trade, organic hops among local consumers?

W hat might this mean for hops work ers?

We believe that a focus on the research questions listed above will help both scholars and policy-makers better understand the trends in farming and farm labor. In particular, we believe that gender needs to be given greater attention in future research on farmworkers. In a concurrent research project, we find that many of the challenges women farmworkers experience, particularly those related to food provisioning, are related to the intersections between socioeconomic status and the form of labor in which they engage (Meierotto \& Som Castellano, in press). We hope that this case study inspires and shapes future research on transitions in agriculture in the American West, across the United States, and globally.

\section{Acknowledgments}

The authors would like to thank undergraduate research assistants Clariza Arteaga and Anna Zigray and graduate research assistant Christopher Torres. The authors also thank the College of Arts and Sciences, Casita Nepantla, and the School of Public Service at Boise State University for pilot research support.

\section{References}

American Organic Hop Grower Association [AO HGA]. (n.d.). M embers. Retrieved August 7, 2018, from http:// www.usorganichops.com/AOHGA/.

Andersson, E., \& Lundqvist, P. (2014). G endered agricultural space and safety: Towards embodied, situated knowledge. Journal of A gromedicine, 19(3), 303-315. https:/ / doi.org/ 10.1080/ 1059924X.2014.916644

Arcia, G., Brantly, E., Hetes, R., Levy, B., Powell, C. ... Whiteford, L. (1993). E nvironmental H ealth A ssessment. a case study conducted in the city of Q uito and the C ounty of Pedro M oncayo, Pichincha Provino, E arador (Field Report 401). Washington, D .C.: Agency for International D evelopment. Retrieved from http:/ / healthpolicy.ucla.edu/ D ocuments/ Newsroom\%20PDF/ PNABR079.pdf

Arcury TA, Laurienti PJ, Talton JW, Chen H, Howard TD , Barr D B, Mora DC, Q uandt SA. (2018). Pesticide Urinary Metabolites Among Latina Farmworkers and Nonfarmworkers in North Carolina. Journal of 0 coupational and E nvironmental M ediane, 60(1), e63-e71. Epub 2017/ 10/ 13. https:/ / doi.org/ 10.1097/ JO M.0000000000001189 
Carney, M. A. (2015). The unending hunger: Traing women and food inseaurity across borders. Berkeley: University of California Press.

Cornelius, W. (2004, May 1). E valuating E nhanœed U.S. Border E nforcement. Migration Policy Institute. Retrieved from https:/ / www.migrationpolicy.org/ article/ evaluating-enhanced-us-border-enforcement

Crowley, M., \& Ebert, K. (2014). New rural immigrant destinations: Research for the 2010s. In C. Bailey, L. Jensen, \& E. Ransom (Eds.), Rural A merica in a globalizing world: Problems and prospects for the 2010s (pp. 401-418). Morgantown: West Virginia University Press.

Crowley, M., Lichter, D. T., \& Tumer, R. N. (2015). Diverging fortunes? Economic well-being of Latinos and African Americans in new rural destinations. Social Scienœ Research, 51, 77-92. https:/ / doi.org/ 10.1016/ j.ssresearch.2014.11.007

Ellis, S. (2017, November 15). Idaho producers seeking H-2A workers could rise significantly. Capital Press. Retrieved from http:/ / www.capitalpress.com/ Idaho/ 20171115/ number-of-idaho-producers-seeking-h-2a-workers-could-risesignificantly

Fan, M., Gabbard, S., Pena, A. A., \& Perloff, J. M. (2014). W hy do fewer agricultural work ers migrate now? (Working Paper \#117-14). Institute for Research on Labor and Employment, University of California, Berkeley. Retrieved from http:/ / irle.berkeley.edu/ files/2014/ Why-D o-Fewer-A gricultural-Workers-Migrate-Now.pdf

Fan, M., \& Perloff, J. M. (2016). Where did all the migrant farm workers go? A RE U pdate, 19(6), 5-7. University of California, Giannini Foundation of Agricultural Economics. Retrieved from https:/ / giannini.ucop.edu/ publications/ are-update/ issues/2016/ 19/6/ where-did-all-the-migrant-farm-workersgo/

Guidotti-Hernández, N. M. (2017). Affective communities and millennial desires: Latinx, or why my computer won't recognize Latina/ o. Cultural D ynamics, 29(3), 141-159. https:/ doi.org/ 10.1177/ 0921374017727853

Holmes, S. (2013). Fresh fruit, brok en bodies: M igrant farmwork ers in the U nited States. Berkeley: University of California Press.

Idaho Business for Education \& J. A. and Kathryn Albertson Foundation. (2015). Idaho education field guide. Retrieved from https:// issuu.com/jkaf/docs/idaho_ed_field guide_v2

Idaho D epartment of Labor (ID L). (2016). Idaho agriaultural employment estimates 2016. Retrieved on February 3, 2016, from https:// lmi.idaho.gov/ farm-labor

Idaho Foodbank, The. (2016). New data shows hunger remains issue in Idaho. Retrieved on February 1, 2016, from https:/ / idahofoodbank.org/ new-data-shows-hunger-remains-major-problem-in-idaho/ [No longer online].

Idaho Preferred. (2014, September 19). H op harvesting in Idaho [Blog post]. Retrieved from https:// idahopreferred.com/2014/ 09/ hop-harvesting-idaho

Kandel, W., \& Cromartie, J. (2004). N ew patterns of H ispanic settlement in rural A merica (Rural D evelopment Report No. 99). U.S. D epartment of Agriculture, Economic Research Service. Retrieved from http:/ / www.latinamericanstudies.org/ latinos/ hispanic-settlement.pdf

Lastarria-Cornhiel, S. (2006). F eminization of agriculture: Trends and driving fores. Rimisp-Latin American Center for Rural D evelopment. Retrieved from https:/ / vtechworks.lib.vt.edu/ bitstream/ handle/ 10919/68838/4589_Lastarria_Cornhiel2006_Feminization_of_A. pdf

Lowe, S., Holley, D., Islam, S., Sandow, J., \& Hurt, M. (2016). A n economic analysis of the hop farming and craft brewing industries in Idaho. Self-published.

Meierotto, L., \& Som Castellano, R. L. (under review). Food provisioning strategies among farm workers in rural Idaho. A griculture and $\mathrm{H}$ uman $\mathrm{V}$ alues.

Minkoff-Zern, L.-A. (2014). Hunger amidst plenty: Farmworker food insecurity and coping strategies in California. L ocal E nvironment, 19(2), 204-219. https:/ / doi.org/ 10.1080/ 13549839.2012.729568

Monnat, S. M. (2017). The new destination disadvantage: D isparities in Hispanic health insurance coverage rates in metropolitan and nonmetropolitan new and established destinations. Rural Sociology, 82(1).

https:// doi.org/ 10.1111/ ruso.12116

National Brewers Association. (n.d.). Statistics: N ational Beer Sales \& Production D ata. Retrieved on O ctober 18, 2018, from https:/ / www.brewersassociation.org/ statistics/ national-beer-sales-production-data/ 
Parrado, E., \& Kandel, W. A. (2010). Hispanic population growth and rural income inequality. Social Foros, 88(3), 14211450. https:/ / doi.org/ 10.1353/ sof.0.0291

Pew Research Center. (2016, November 3). H ispanic trends: U.S. unauthorized immigrant population, by state, 2014. Retrieved from http:/ / www.pewhispanic.org/ interactives/ unauthorized-immigrants/

Rott, N. (2015, D ecember 24). A tiny town in Idaho welcomes the state's first all-Latino city council [Radio broadcast story]. N PR A 11 Things C onsidered. Retrieved from https:/ / www.npr.org/ 2015/ 12/ 24/ 460959623/ small-town-set-toswear-in-idahos-first-all-latino-city-council

Runkle, J. D ., Tovar-Aguilar, J. A., Economos, E., Flocks, J., Williams, B., Muniz, J. F. ... McCauley, L. (2013). Pesticide risk perception and biomarkers of exposure in Florida female farmworkers. Journal of 0 coupupational and $\mathrm{E}$ nvironmental M edicine, 55(11), 1286-1292. https:// doi.org/ 10.1097/ JO M.0b013e3182973396

Schmalzbauer, L. (2014). The last best plaœ? G ender, family, and migration in the new W est. Palo Alto, CA: Stanford University Press.

U.S. Census Bureau. (2018). Census Bureau Q uick Facts. Retrieved August 6, 2018, from https:/ / www.census.gov/

U.S. D epartment of Agriculture, Economic Research Service [USD A ERS]. (2018). Farm Labor Retrieved January 29, 2019. https:/ / www.ers.usda.gov/ topics/ farm-economy/ farm-labor/

U.S. D epartment of Agriculture, National Agricultural Statistics Service [USD A NASS]. (2014). Farm demographics- U.S. farmers by gender, age, raœ, ethnicity and more: M inority principal operators, 2007 and 2012 [Chart]. Retrieved January 29, 2019, from https:/ / www.nass.usda.gov/ Publications/ Highlights/2014/ Farm_Demographics/index.php

USD A NASS. (2016). N ational hop report. Retrieved from https:// www.nass.usda.gov/Statistics by_State/Regional_Office/Northwest/includes/Publications/Hops/hopsan 16.pdf

USD A NA SS. (2018, July 2). H op areage in the N orthwest Region up 4 percent for 2018. Reoord high acreage at U .S. level [Press release]. Retrieved from https:// www.nass.usda.gov/Statistics_by_State/ Regional_Office/ Northwest/includes/ Publications/ Hops/ HOP06 01.pdf

U.S. D epartment of Labor [USDL]. (2005). Findings from the N ational A grialtural W ork ers Survey (N A W S): A demographic and employment profile of U nited States F armwork ers 2001-2002 [Not currently online].

USD L. (2016). Findings from the N ational A griaultural W ork ers Survey (N A W S) 2013-2014: A D emographic and E mployment Profile of U nited States F armwork ers (Report No 12). Retrieved from https:// www.doleta.gov/agworker/pdf/NAWS Research Report 12 Final 508 Compliant.pdf

University of Idaho, McClure Center for Public Policy Research. (2016). Idaho at a glance. H ispanics: 0 verview, 7 (2). Retrieved from https:// www.uidaho.edu/ -/ media/ UIdaho-Responsive/ Files/ presidents-office/ directreports/mcclure-center/Idaho-at-a-G lance/ IAG-hispanics-an-overview.pdf

Wasserman E. (1999). Environment, health, and gender in Latin America: Trends and research issues. E nvironmental Research, 80 (3), 253-273. https:/ / doi.org/ 10.1006/ enrs.1998.3943

Wiltz, T. (2015, August 14). Hispanic poverty in rural areas challenges states [Blog post]. Pew Research Center. Retrieved from https:/ / www.pewtrusts.org/ en/ research-and-analysis/ blogs/ stateline/ 2015/ 08/ 14/ hispanic-poverty-in-ruralareas-challenges-states

Zhang, X., Zhao, W., Jing, R., Wheeler, K., Smith, G. A., Stallones, L., \& Xiang, H. (2011). Work-related pesticide poisoning among farmers in two villages of Southern China: A cross-sectional survey. BM C Public H ealth, 11, 429. https:// doi.org/ 10.1186/ 1471-2458-11-429 